\title{
IDU AND THE TREATMENT OF HERPES SIMPLEX KERATITIS*
}

\author{
BY

\section{S. I. DAVIDSON AND P. JAMESON EVANS \\ Birmingham and Midland Eye Hospital}

5-IODO-2'-DEOXYURIDINE (IDU) is an antimetabolite that acts by displacing thymidine from deoxyribonucleic acid (DNA). This results in inhibition of DNA synthesis, which particularly affects virus particles in the active replication of herpes simplex keratitis in rabbits (Kaufman, Nesburn, and Maloney, 1962; Perkins, Wood, Sears, Prusoff, and Welch, 1962). Following the report of effective treatment with IDU of human herpes simplex keratitis in an uncontrolled trial (Kaufman, Martola, and Dohlman, 1962), many publications have reiterated the efficacy of the drug (for example, Corrigan, Gilkes, and Roberts, 1962; Bennett, 1962; Havener and Wachtel, 1963; Maxwell, 1963; Gordon and Karnofsky, 1963). Despite the fact that the majority of favourable reports on the efficacy of IDU have rested on uncontrolled trials of the drug, there have surprisingly been few attempts to produce objective results by means of double-blind controlled clinical trials. Notable exceptions are the papers of Burns (1963), Patterson and others (1963) and Jepson (1964), but these are open to some criticism. The clinical diagnosis of herpes simplex infection was not confirmed by virus culture in any of these trials and there was no indication whether any other therapy had been administered before admission to the trial. Moreover, in these studies the patients received cycloplegics, and Patterson and others in addition used hot bathings, and steroids may have been used in the group of patients studied by Burns. Burns and Patterson and others treated their cases as outpatients attending daily whenever possible, and there were multiple observers in both of these trials. Jepson's patients were seen at weekly intervals.

The clinical experience of some observers has been less uniformly successful (Davidson, 1962; Luntz and MacCallum, 1963; Thygeson, Sexton, and Corwin, 1963). In view of the disparity in these observations we determined on a doubleblind trial of the drug IDU, for no report on a strictly controlled trial was then available.

In constructing the trial we fully realized the advantage in using "control" drops as a placebo. However, herpes simplex keratitis is a serious and blinding disease and we felt it would be unjustifiable to give no treatment at all. (See Bradford Hill, 1963, and British Medical Journal, 1963). We resolved the difficulty by using as "control" drops a 1 per cent. solution of gamma globulin, which has not been conclusively shown to be ineffective in the treatment of human herpes simplex keratitis and might be expected to raise the level of antibodies locally. 
It was also felt essential to compare these two groups with patients given conventional therapy, and accordingly a third group of patients was treated with iodization as a primary procedure.

\section{Material and Methods}

\section{Selection of Patients}

The trial was confined to patients with fresh herpes simplex keratitis without stromal involvement, and to patients with a recurrence of a previous herpes simplex keratitis affecting the epithelium or with minimal stromal involvement only. None of the patients included in the trial had received other forms of therapy of any type. As long as the corneal stroma remained basically uninvolved, the duration of the keratitis was considered unimportant. Patients of both sexes and any age were treated.

\section{Treatment Schedules}

Three groups of 25 patients were treated as follows, groups $(a)$ and $(b)$ being admitted to hospital for the first week of treatment:

(a) IDU drops ( $0 \cdot 1$ per cent. solution) hourly during the day and 2-hourly at night, with no other therapy apart from a pad and bandage.

(b) Gamma globulin drops (1 per cent. solution) with the same frequency as in group (a), together with a pad and bandage.

(c) Iodization of the affected areas of the cornea with an alcoholic solution of iodine and potassium iodide, together with topical therapy of atropine 1 per cent. drops twice daily and chloramphenicol ointment 1 per cent. three times a day. A pad and bandage was also applied.

IDU solution $(0 \cdot 1$ per cent.) was prepared by dissolving IDU powder in distilled water and adding 0.002 per cent. thiomersal as preservative. In view of doubts expressed as to the stability of IDU solution at room temperature (Gilkes, 1963; Maloney and Kaufman, 1962), all drops were refrigerated between applications, though it has been shown that the IDU solution is stable at normal room temperature (Davidson, 1963).

Iodization was performed on the dry cocainized cornea by the removal of all staining epithelium with an orange stick, round which a wisp of cotton wool had been wrapped, lightly dipped in an alcoholic solution of iodine and potassium iodide.

\section{Allocation of Treatment}

The patients admitted to the trial were allocated to one of the three groups using randomized sample tables, with which the pharmacist was provided. The usual precautions of a double-blind clinical trial were followed, e.g. the observer was unaware of the type of drop being administered.

\section{Assessment of Results and Follow-up}

A full clinical assessment was made before therapy commenced. Every patient in the trial was examined daily with the slit lamp by the same observer. Healing was judged to have occurred by the absence of staining with 2 per cent. fluorescein. The clinical observations were recorded on a standard card, each ulcer being sketched 
daily. The response to therapy was graded in the following manner:

Excellent-no staining within seven days

Good-major part of stain healed by 7 days and subsequently complete within further 7 days

Fair-some reduction in extent of stain but no healing within 14 days

Poor-little or no reduction in stain after 14 days

The therapy of groups $(a)$ and $(b)$ was continued for a week whilst in hospital and if healing occurred, they were maintained on the same drops for a further week on discharge.

Each patient was followed up from the commencement of the trial in order to record the rate of recurrence especially in successful cases.

\section{Laboratory Investigations}

In every case a small scraping was taken from the margin of the dendritic patterns with a wire loop or a corneal spud and inoculated into tissue culture medium for virus isolation.

The serum gamma globulin level was estimated before treatment was begun.

\section{Results}

Group (a).-Of the 25 patients in this group, eight were rejected as tissue culture was negative for virus. The remaining seventeen patients responded to IDU (Table I).

Group $(b)$.- Of the 25 patients in this group, virus could not be grown in eleven. The remaining fourteen patients responded to gamma globulin drops (Table I).

TABLE I

RESULTS OF TREATMENT IN ULCERS FROM WHICH VIRUS WAS ISOLATED

\begin{tabular}{|c|c|c|c|c|c|c|}
\hline \multirow{3}{*}{ Result } & \multicolumn{6}{|c|}{ Treatment } \\
\hline & \multicolumn{2}{|c|}{ (a) IDU } & \multicolumn{2}{|c|}{ (b) Gamma Globulin } & \multicolumn{2}{|c|}{ (c) Iodization } \\
\hline & No. & Per cent. & No. & Per cent. & No. & Per cent. \\
\hline Excellent & 7 & $41 \cdot 4$ & 3 & $21 \cdot 4$ & 9 & \\
\hline Good & 1 & $5 \cdot 8 \int^{4 / 2}$ & 4 & $\overline{28 \cdot 5}\}^{44 \cdot 9}$ & 6 & $30\}^{13}$ \\
\hline Fair & 5 & $29 \cdot 4$ & 4 & $28 \cdot 5$ & 5 & 25 \\
\hline Poor & 4 & $23 \cdot 5$ & 3 & $21 \cdot 4$ & 0 & - \\
\hline Total & 17 & 100 & 14 & 100 & 20 & 100 \\
\hline
\end{tabular}

Group $(c)$.- Of the 25 patients in this group, virus could not be isolated in five. The remaining twenty patients responded to iodization with topical atropine drops and chloramphenicol ointment (Table I).

There were 24 cases rejected because virus was not isolated from the ulcers, eight cases in Group (a), eleven in Group (b), and five in Group (c). However, if these cases are included in the various groups, the results shown in Table II (opposite) are obtained.

There were eight cases of recurrence of the herpes simplex keratitis (Table III, opposite); herpes simplex virus had been cultured initially in all of them. 
TABLE II

RESULTS OF TREATMENT IN ALL CASES IGNORING VIRUS CULTURE

\begin{tabular}{|c|c|c|c|c|c|c|}
\hline \multirow{3}{*}{ Result } & \multicolumn{6}{|c|}{ Treatment } \\
\hline & \multicolumn{2}{|c|}{ IDU } & \multicolumn{2}{|c|}{ Gamma Globulin } & \multicolumn{2}{|c|}{ Iodization } \\
\hline & No. & Per cent. & No. & Per cent. & No. & Per cent. \\
\hline Excellent & 12 & \multirow{2}{*}{$\left.\frac{40}{8}\right\}^{56}$} & 8 & \multirow{2}{*}{$\left.\frac{32}{20}\right\} 52$} & 10 & \multirow{2}{*}{\} 80} \\
\hline Good & 2 & & 5 & & 10 & \\
\hline Fair & 6 & 24 & 5 & 20 & 5 & 20 \\
\hline Poor & 5 & 20 & 7 & 28 & 0 & - \\
\hline Total & 25 & 100 & 25 & 100 & 25 & 100 \\
\hline
\end{tabular}

TABLE III

RECURRENCES

\begin{tabular}{l|c|c}
\hline \multicolumn{1}{c|}{ Treatment } & Number of Cases & Interval before Recurrence (mths) \\
\hline IDU & 4 & $1,1 \frac{1}{2}, 2,5$ \\
\hline Gamma globulin & 2 & $1,2 \frac{1}{2}$ \\
\hline Iodization & 2 & 2,3 \\
\hline
\end{tabular}

The serum gamma globulin results showed no marked variation and bore no relation to the therapeutic response with the various agents. An average figure of $1 \cdot 15 \mathrm{~g}$. per cent. was obtained.

There were no allergic reactions to the drops, nor were there any complaints of burning or irritation. Some areas of punctate stain were noted after healing with IDU or gamma globulin drops, but these were no more frequent than after iodization.

\section{Discussion}

Our results (Table I) indicate that iodization is the most effective healing procedure, IDU the next best, and gamma globulin the least efficient. If the excellent and good results (corresponding to healing within 1 and 2 weeks respectively) are combined, it becomes apparent that iodization is by far the most efficient procedure. Table I also suggests that healing induced by IDU will occur within the first week, little improvement taking place thereafter. Moreover, there is little difference in the overall healing rate at the end of 2 weeks between IDU and the relatively ineffective gamma globulin.

Inclusion of all the cases treated, i.e. 25 in each of the three groups, ignoring the virus isolation studies, caused no marked variation in the results obtained ( $c f$. Tables I and II). The greater numbers considered increase the validity of these results and strengthen the observations made above. 
The therapeutic efficiency of IDU as indicated in our results ( 41.4 per cent.) can in no way compare to the 76 per cent. of successful results reported by Patterson and others (1963) or the 92 per cent. reported by Jepson (1964). We have found iodization to be therapeutically superior, and support is lent to this conclusion by the observations of Mackenzie (1964) and Ey, Hughes, Holmes, and Deinhardt (1964) on cauterizing agents. However, iodization often causes great discomfort to the patient in the 24 hours following cauterization, the eye remaining irritable for several days afterwards. Taking cognizance of our results, it would therefore seem reasonable to adhere to our original view (Davidson, 1962), that primary treatment with IDU is justifiable in herpes simplex keratitis but that, should healing not occur within 7 days, iodization is indicated.

We should like to interject a note of caution regarding the technique of iodization for we have seen cases wherein it has been apparent that too vigorous a scrub has resulted in a break in Bowman's membrane leading to a violent chemical keratitis.

A surprising feature of our results was the number of cases (49.9 per cent.) which healed within 2 weeks whilst on gamma globulin drops. We do not think that this was related to the therapeutic efficiency of the gamma globulin but that it was a manifestation of the natural rate of remittance. Jepson (1964) demonstrated a high rate (75 per cent.) of spontaneous improvement in his control group, and Patterson and others (1963) found an unexpectedly high proportion of cures (38 per cent.) among their controls. Thygeson, Kimura, and Hogan (1956) have suggested that the natural rate of remittance of herpes simplex keratitis is 10 per cent., but our results and those of other workers previously mentioned indicate that this figure may well have to be revised. Moreover, as Jepson (1964) has emphasized, this relatively frequent spontaneous remission of herpes simplex infections of the cornea must be taken into account in assessing the efficacy of any drug.

Our trial was begun in April, 1963, and all cases have been followed up since then, the minimum interval after healing being 3 months. A relatively high recurrence rate (Table III) has been noted amongst the cases treated with IDU. This more frequent recurrence rate following successful IDU therapy concurs with the observations of Patterson and others (1963). Although the numbers are few, the figures also suggest that recurrences may occur earlier after healing with IDU.

It had been shown that IDU retards healing in the corneal stroma (Polack and Rose, 1964) and our own results have demonstrated that little healing occurs with IDU after one week should the initial therapeutic response have been poor. Thus to continue using IDU beyond one week in the absence of signs of healing might allow the virus to breach Bowman's membrane and enter the corneal stroma where the healing processes are already being suppressed by the IDU.

\section{Summary}

The treatment of herpes simplex keratitis with IDU and gamma globulin drops was compared in a double-blind clinical trial. A further group of patients treated by iodization was included in the study.

The results indicated that iodization was the most efficient therapeutic procedure.

IDU drops induced a higher rate of healing than gamma globulin drops during the first week of treatment, but there was little difference in the overall healing rate 
between the two agents at the end of 2 weeks. Healing with gamma globulin drops may be a manifestation of a higher spontaneous remission rate of herpes simplex keratitis than has been previously appreciated.

We are grateful to the surgeons of the Birmingham and Midland Eye Hospital for permission to treat their patients. Our thanks are also due to Dr. J. C. MacDonald for the supply of gamma globulin and to Dr. B. R. Sandiford for having carried out the virus isolation studies. We are also indebted to Miss A. R. Warren, our pharmacist, and to the resident medical staff for their ready co-operation. Dr. J. Johnston of Smith Kline \& French Ltd. readily made supplies of IDU available to us and we should like to acknowledge his willing help.

BENNETT, F. (1962). Lancet, 2, 726.

British Medical Journal (1963). 2, 1.

BURNS, R. P. (1963). Arch. Ophthal. (Chicago), 70, 381.

Corrigan, M. J., Gilkes, M. J., and Roberts, D. St. Clair (1962). Brit. med. J., $2,304$.

DAVIDSON, S. I. (1962). Lancet, 2, 1326. (1963). Ibid., 1, 555.

Ey, R. C., Hughes, W. F., Holmes, A. W., and Deinhardt, F. (1964). Arch. Ophthal. (Chicago), $71,325$. GILKES, M. J. (1963). Lancet, 1, 227.

Gordon, D. M., and KARNofSky, D. H. (1963). Amer. J. Ophthal., 55, 229.

HAVENER, W. H., and WACHTEL, J. (1963). Ibid., 55, 234.

Hill, A. BRADFORD (1963). Brit. med. J., 1, 1043.

JEPSON, C. N. (1964). Amer. J. Ophthal., 57, 213.

-, Martola, E. L., and Dohlman, C. (1962). Arch. Ophthal. (Chicago), 68, 235.

Kaufman, H. E., Nesburn, A. B., and Maloney, E. D. (1962). Ibid., 67, 583.

LunTZ, M. H., and MacCAllum, F. O. (1963). Brit. J. Ophthal., 47, 449.

MACKENZIE, A. D. (1964). Ibid., 48, 274.

Maloney, E. D., and Kaufman, H. E. (1962). Cited by Burns (1963).

MaXWell, E. (1963). Amer. J. Ophthal., 55, 237.

Patterson, A., and eight others (1963). Trans. ophthal. Soc. U.K., 83, 583.

Perkins, E. S., Wood, R. M., Sears, M. L., Prusoff, W. H., and Welch, A. D. (1962). Nature (Lond.), 194, 985 .

PolaCK, F. M., and Rose, J. (1964). Arch. Ophthal. (Chicago), 71, 520.

Thygeson, P., Kimura, S. J., and Hogan, M. J. (1956). Ibid., 56, 375.

—, Sexton, R. R., and Corwin, M. E. (1963). Trans. Pacif. Cst oto-ophthal. Soc., 44, 81. 